\title{
Kazimierz Szmyd, Twórcy nauk o wychowaniu w środowisku akademickim Lwowa (1860 - 1939), Wydawnictwo Uniwersytetu Rzeszowskiego, Rzeszów 2003, ss. 530
}

Dla miłośników dziejów Lwowa Wydawnictwo Uniwersytetu Rzeszowskiego przygotowało kolejną pozycję książkową. Jest nią obszerna praca Kazimierza Szmyda pt. „Twórcy nauk o wychowaniu w środowisku akademickim Lwowa (1860-1939)".

Istnieje co prawda wiele książek o Lwowie, ta prezentowana jednak zdecydowanie się wyróżnia, i to nie tylko objętościa. Sam autor we wprowadzeniu zaznaczył, iż jego praca powstała nie tylko ze względów i potrzeb historycznych. K. Szmyd napisał, że „w jednoczacej się Europie, poszukiwanie idei i zasad zgodnego współistnienia, konstruowanie teleologii wychowawczej umożliwiającej przezwyciężanie irracjonalnych uprzedzeń i podziałów jest nie mniej ważne niż na przełomie XIX i XX wieku"', w wieloetnicznej stolicy Galicji. I zaiste, jest to motywacja ze wszech miar godna zauważenia!

Inne cele badawcze autora są również ambitne: ustalenie i wyjaśnienie genealogii i uwarunkowań społeczno-kulturowych, środowiskowych i historycznych filozoficzno-naukowej myśli pedagogicznej i oświatowej Lwowa, przy całym bogactwie i zapleczu intelektualnym lwowskich tradycji; ukazanie na ile odrębny i samodzielny byl lwowski nurt myślowy zorientowany na pedagogikę; opisanie ,niepowtarzalnego" klimatu naukowego panującego w Galicji; ustalenie miejsca lwowskiego środowiska nauk o wychowaniu na tle ogólnopolskiej myśli i teorii edukacyjnej ${ }^{2}$.

Tak zarysowana motywacja badawcza wplynęła na kształt i budowę pracy. Składa się nań siedem rozdziałów, bogate zestawienie bibliografii, liczne aneksy, indeks nazwisk i krótkie streszczenie w języku niemieckim i rosyjskim.

Rozdział pierwszy, wprowadzający, przedstawia Lwów jako metropolię wielonarodowościowej prowincji i wiclokulturowej społeczności uniwersyteckiej. Znaczna część rozważań K. Szmyda w tym miejscu poświęcona jest losom Uniwersytetu Lwowskiego. W rozdziale kolejnym natomiast autor rekonstruuje rodowody i początki pedagogiki akademickiej we Lwowie. Zaznacza przy tym, iź były to początki wielonarodowe i ściśle powiązane $\mathrm{z}$ niemieckojęzyczna kultura pedagogiczną. Elementem rozdziału sa także przedstawione sylwetki prekursorów i twórców lwowskiej pedagogiki akademickiej (M.W. Voigta, ks. J. Fredrowicza, I. Pollaka, G. Jachimowicza, ks. L. Malinowskiego, F. Kostka). Uzupełnieniem i uwieńczeniem tej części pracy jest przedstawienie różnorodnych form (głównie wykładów) nauczania pedagogiki na Uniwersytecie Lwowskim. Rozdział trzeci ukazuje lwowska pedagogikę $w$ dobie polonizacji i samookreślenia akademickiego. Głównym bohaterem tego okresu jest E. Czerkawski, a także kontynuatorzy pedagogiki akademickiej: A. Raciborski, J. Ochorowicz, A. Skórski, A. Danysz, B. Mańkowski. Lwowska pedagogika w opisywanym okresie oznaczała także kształcenie dla nauczycieli szkół średnich, gimnazjów i szkół realnych. Stąd autor nakreślił także w tym rozdziale dzieje pierwszego Seminarium Pedagogicznego. Część czwarta pracy nosi tytuł ,W kręgu tradycji filozoficznej i poszukiwań tożsamości naukowej psychologii i pedagogiki". Owa tradycja oznacza dla K. Szmyda głównie szkołę filozoficzną K. Twardowskiego. Autor także w tym miejscu analizuje i porównuje status i znaczenie akademickie dwóch, bliskich sobie, dyscyplin: psychologii i pedagogiki. Kolejny, piąty, rozdział przedstawia Uniwersytet im. Jana Kazimierza (dawny Uniwersytet Lwowski) w okresie II Rzeczypospolitej. A dokładniej, starania uczelni o uzyskanie przez nauki o wychowaniu należytej edukacyjnej pozycji i naukowej rangi, ich drogę do samodzielności. Następny, szósty, rozdział jest niejako kontynuacja wcześniejszych rozważań. Poświęcony jest w całości naukom o wychowaniu na UJK w kontekście edukacji pedagogicznej. Stąd autor rysuje strukturę, organizację i programy studiów pedagogicznych i psychologicznych, sylwetki wykładowców i studentów. Przedstawia także sylwetki uczonych, bardzo dobrze kojarzonych z naukami 
o wychowaniu: S. Eempickiego i K. Sośnickiego. Pojawiaja się także M. Ziemnowicz, M. Kreutz i, po raz kolejny, K. Twardowski. Rozważania K. Szmyda kończy siódmy rozdział, będący jednocześnie próba konkluzji i oceny lwowskiego środowiska nauk o wychowaniu.

Bibliografia zebrana przez autora na końcu pracy jest imponująca, chociaż przedstawiona jest jedynie w wyborze. K. Szmyd wnikliwie zbadał zasoby archiwów, niestety jedynie ukraińskich, może należało także przejrzeć zbiory, np. wrocławskiego Ossolineum? Zastanawia mnie również fakt doboru opracowań; autor bowiem podaje je w wyborze, czyni to jednak dublujac niektóre pozycje, np. podaje tytuły prac zbiorowych (pokonferencyjnych), a zaraz potem wymienia poszczególne artykuły $w$ nich zawarte. Podobnie jest $\mathrm{z}$ czasopismami: najpierw sa one wymienione (bez roczników, niestety) jako osobna kategoria bibliografii, a następnie w opracowaniach odnaleźć można konkretne prace w tychże czasopismach drukowane. Do źródel drukowanych zaliczyłabym także, inaczej niż zrobił to autor pracy, wymienione $w$ opracowaniach, dzieła twórców nauk o wychowaniu, pisane jeszcze często w wieku XIX.

Czy autorowi udało się zrealizować postawione sobie na początku pracy cele? Czy motywy, jakimi kierował się przy wyborze tematu okazały się wystarczające? Czy dzieło K. Szmyda, ,Twórcy nauk o wychowaniu w środowisku akademickim Lwowa (1860-1939)" jest nowatorskie i wypełnia jakąkolwiek lukę w bibliografii?

Na wszystkie te pytania należy odpowiedzieć twierdząco. Można nawet stwierdzić, iż autor zdołał poruszyć znacznie szerszą problematykę, niźli wskazuje tytuł pracy, bo oto nie mamy przed oczyma jedynie naszkicowanych kilku portretów twórców nauk o wychowaniu we Lwowie, ale obszerną rozprawę, będącą udaną rekonstrukcja środowiska akademickiego i tradycji pedagogicznych $w$ wielokulturowym i fascynującym miejscu, jakim była stolica Galicji. Każda społeczność akademicka powinna postarać się, by prace tego typu stały się jej udziałem.

Edyta Gtowacka-Sobiech

1 S. 9.

2 S. $11-13$.

\section{Iwona Wendreńska, Dydaktyka ogólna jako przedmiot kształcenia nauczycieli w Drugiej Rzeczypospolitej (1918 - 1939), Wydawnictwo Uniwersytetu Sląskiego, Katowice 2003, ss. 171}

W dobie aktualnych przemian społecznych, politycznych, kulturowych i innych zmienia się spojrzenie na nauczyciela. Często współczesnemu nauczycielowi wyznacza się rolę promotora przemian jakościowych w edukacji, w kształtowaniu charakteru nowego pokolenia. Fakt ten pociaga za sobą m.in. przewartościowanie dotychczas pożądanych kompetencji zawodowych nauczyciela. Oczekiwania i wymagania wobec nauczycieli sa i prawdopodobnie będą coraz większe. Tymczasem obowiązujące modele kształcenia, nastawione głównie na wyposażenie przyszłych nauczycieli w wiedzę teoretyczną z określonej dziedziny wydają się niewystarczające dla ich spełnienia. W dyskusjach nad problematyką przygotowania nauczycieli do wypełniania roli zawodowej, nabywania określonych kompetencji pojawiaja się coraz częściej postulaty dotyczące konieczności wprowadzenia zmian nie tylko w siatkach godzin poszczególnych instytucjonalnych form kształcenia nauczycieli, ale także w celach, treściach, technologii kształcenia różnych przedmiotów, a zwłaszcza dydaktyki ogólnej. Rozprawa Iwony Wendreńskiej pt. „Dydaktyka ogólna jako przedmiot kształcenia nauczycieli w Drugiej Rzeczypospolitej (1918 - 1939)" włącza się w nurt refleksji nad dydaktyka ogólną jako przedmiotem kształcenia nauczycieli szkół ogólnokształcących. Praca ma charakter monografii historyczno-pedagogicznej i dotyczy dydaktyki ogólnej jako przedmiotu 